\title{
EFFECT OF HEATING SYSTEM ON TEMPERATURE STRATIFICATION INSIDE THE BROILER HOUSING
}

\author{
Ghoname, M. S*, A.A, Derbala ${ }^{* *}$, T.Z. Fouda ${ }^{* * *}$, and \\ S. M.AbdelLatif ${ }^{*}$
}

ABSTRACT

The experimental work was carried out in private broiler house at Babel village, Menofia Governorate, during the winter season of 2011 in order to reduce the temperature stratifications that usually occurred in the broiler housing when using forced air heating system with and without perforated polyethylene duct. The air temperatures just above the floor surface and underneath the ceiling ambient floor and ceiling were continuously measured. The broiler performance evaluation was also determined in terms of feed conversions efficiency, production index, and efficiency rate of production. The obtained results showed that, when using forced air heating without polyethylene duct temperature stratification ranged between 0.4 and $5.93{ }^{\circ} \mathrm{C}$. Whereas, employing the forced air furnace with perforated duct, led to minimize the temperature stratification to $-2.9^{\circ} \mathrm{C}$ and $0.043^{\circ} \mathrm{C}$ during the first two days age. Using forced air furnace with perforated duct increased feed conversions efficiency, production index and efficiency rate of production from 60.4 to $65.2 \%, 114.8$ to $130.6 \%$ and from 306.83 to $347.06 \%$, respectively. While, the feed conversions ratio decreased from 1.65 to 1.60 after five weeks age.

\section{INTRODUCUTION}

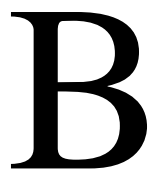

roiler houses management during winter condition offers challenges in environmental control because it is necessary to keep birds warm enough with good air quality within competing function of heating air to acceptable temperature for the birds. The ambient temperature requirements of domestic chicks change with age,

\footnotetext{
*Demonstrator in Agric. Eng. Dept ., Fac. of Ag., Tanta .Univ.

${ }^{* *}$ Associate Professor in Agric. Eng. Dept ., Fac. of Ag.,Tanta .Univ.

${ }^{* * *}$ Prof . of Agric. Eng. Dept ., Fac. of Ag.,Tanta .Univ.

${ }^{* * * *}$ Prof . of Agric. Eng. Dept ., Fac. of Ag., Mansoura .Univ.
} 
In the first week their body temperature, metabolic rate, body mass to surface area ratio, insulation from feathering and thermoregulatory ability are all relativity low. Lacy, (1997) revealed that, a newly hatched chick placed in a cool environment, its internal body temperature begins to drift downward toward the environmental temperature and may reduce the growth efficiency of the bird. In broiler houses, floor temperature is often 2.8 to $8.3^{\circ} \mathrm{C}$ below air temperature. The temperature of the broiler house floor during brooding is more important than air temperature, since chicks are in direct contact with the floor. Even fairly brief exposure to cool floors can adversely affect chicks. Czaric and lacy (2000a) indicated that, in boiler houses with forced air furnace the best way to insure that the brooding at the proper temperature is to place thermostat/sensor $7.6-10 \mathrm{~cm}$ above the floor. This should be high enough that the chicks can not reach them. Once the birds are a week to ten days of age the thermostat/sensor should be raised $60 \mathrm{~cm}$ of floor so birds cannot peck at thermostat/sensor or site on them. Czaric and lacy (2000b) reported that the primary reason for move to radiant/conventional brooders has to do with the very nature of forced air furnaces. The hot air coming from a furnace does not move a long the floor keeping the chicks warm, but rather, rises quickly to the ceiling of the house keeping the ceiling warm. Therefore, in order to get the hot air down to chick level it should keep on filling up the ceiling of the house with hot air until added enough heat to make it down to level. Dozier and Donald (2001) reported that, if chicks are chilled, nutrients that might have been used for body development are used to maintain body heat. Chilled chicks also tend to huddle together, and most do not seek out feed or water, so a number of birds may die. The performance of the chicks that survive chilling is likely to be limited due suppressed digestive or immune system functions. Periods of extended cold stress force the chick to begin breaking down the carbohydrates and fats in its own body tissues to maintain body heat, since it is unable to acquire enough from the feed alone. The proper temperature for brooding broiler chicks will depend on the system being used. However, it is important to realize that supplemental heat will be required even in the summer and especially at night. Czaric and Fairchild (2005) found that, during 
heating process of the broiler house with forced air furnace the average temperature near the floor surface was $27.8^{\circ} \mathrm{C}$ while at ceiling it was over $37.8^{\circ} \mathrm{C}$. Thought a ten degree difference between floor and ceiling is a problematic from a heating cost and chick performance. Fairchild (2009) reported that, chick develops the ability to regulate its body temperature around 12 to14 days of age, and body temperature of a day-old chick is approximately $39^{\circ} \mathrm{C}$, but about five days of age it rise to be $41.1^{\circ} \mathrm{C}$, the same as adult. The young chick is dependent on environmental temperature. Brooding temperature will vary depending on whether the heat source is forced air furnace, conventional brooder or radiant brooder. A house with forced furnace requires higher brooding temperature settings. A conventional pancake brooder directs approximately $40 \%$ of its heat to the floor and $60 \%$ to the air. Radiant brooders project approximately $90 \%$ of their heat to the floor and $10 \%$ to the air. Because pancake and radiant brooders direct more heat to the floor, the air temperature required to get the desired floor temperature is less than that required for forced air furnace. It is recommended that, the brooding floor temperature must be $34^{\circ} \mathrm{C}$ during the first week and decrease about $3^{\circ} \mathrm{C}$ every week until the end of living cycle to reach $22^{\circ} \mathrm{C}$.

\section{The main objectives of theses study are to:}

1 - Reduce temperature stratification in broiler housing

2 -Improve broiler performance

\section{MATERIALS AND METHODS}

The experimental work was executed in private broiler house at Babel village, Menofia Governorate (latitude and longitude angles are $30.67^{\circ} \mathrm{N}$ and $30.98^{\circ} \mathrm{E}$, respectively) during the winter season of 2011 in order to reduce temperature stratification that usually occurred in the broiler housing and improve the broiler performance. The geometric characteristics of the broiler house are as follows; length, $35 \mathrm{~m}$, width, 15 $\mathrm{m}$, height, $3.1 \mathrm{~m}$, floor surface area, $525 \mathrm{~m}^{2}$, and house volume, 1627.5 $\mathrm{m}^{3}$. It is orientated with East-West direction. The experiment was conducted in two successive living cycles, each cycle having total complement of 5000 birds one day age (Cobb hybrid). The forced air 
heating system was employed to provide and maintain the desired level of air temperature. In the first living cycle the house heating was executed using forced air heating system. Whereas, in the second living cycle the house heating was performed using forced air heating system connected with polyethylene perforated duct situated $2.0 \mathrm{~m}$ above the floor surface with an aperture coefficient of 1.7.

\section{Heating system}

Forced air furnace (E-120BABYSER) consists of furnace, heat exchanger, axial fan, and electric control box was functioned during the experiment period.

A- Furnace: the combustion chamber is made of stainless steel (AIS430), height chromium contents with $60 \mathrm{~cm}$ diameter and $85 \mathrm{~cm}$ long.

B- Heat exchanger: The heat exchanger is a counter flow it consists of 28 oval shaped pipes with gross dimensions of $7 \mathrm{~cm} \mathrm{x} 4 \mathrm{~cm}$ and $95 \mathrm{~cm}$ long, as shown in Fig. (1).

C- Fan: Forced axial fan with $75 \mathrm{~cm}$ in diameter, taken its motion directly from an electric motor 3 phase, and $1.5 \mathrm{~kW}$ power. The fan air exchange rate is $11,000 \mathrm{~m}^{3} / \mathrm{h}$.

\section{Perforated duct:}

Polyethylene duct with diameter of $61 \mathrm{~cm}$ and $0.240 \mathrm{~mm}$ was punched to provide circle holes of $5 \mathrm{~cm}$ diameter in order to distribute the hot air inside the broiler house.

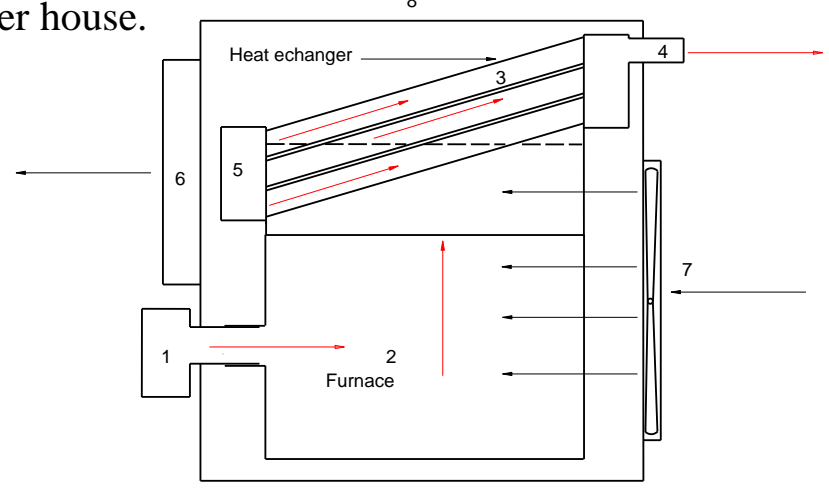

Fig. (1): Schematic diagram of Forced air furnace heating system

1- Gas burner

4- Chimney tube

7- Axial fan
2- Furnace 3- Oval heat exchanger tube

5- Exchanger inspection door 6- Air out let 8- Heater body 


\section{Instrumentations}

\section{a-The global positioning system Gps}

A global positioning system was used to determine the private broiler house coordinates with accuracy of \pm 5 meters.

\section{b- Data logger}

Two data-logger devices (16 channels) were used for collecting and recording reading from the different sensors (Thermistors) located at different positions inside the broiler house. Each data-logger having keyboard and monitor. Two computer programs (Lap Jack and Profilap) were employed. The Lap Jack program was used to run the data-logger on the computer and the Profilap was functioned to convert the reading from analog to digital. The time interval for data recording was 5 minutes with data acquisition every one minute for integrated measurements. The calibration of all sensors and the logger were completed successfully at the beginning of the experimental work.

\section{Measurements}

\section{Temperature measurements}

Sensors were used to measure air temperatures inside and outside the broiler house. Inside the house air temperatures were measured in two different levels at height of $25 \mathrm{~cm}$ above the floor surface and $10 \mathrm{~cm}$ underneath the ceiling. The chick's body temperature was measured using infrared thermometer, then the temperature averages was taken in calculation.

\section{Calculation}

\section{Aperture coefficient}

The aperture coefficient and number of circle holes were calculated using the following equation (George, 1997):

$$
\text { Aperature coefficient }=\left(\frac{\text { Holes total area }}{\text { Duct cross- section area }}\right)
$$

\section{Feed conversion efficiency (FCE)}

Broilers feed conversion efficiency was computed using the following formula:

$$
\mathrm{FCE}=\frac{\mathrm{W}_{\mathrm{b}}}{\mathrm{F}_{\mathrm{C}}} \times 100
$$


Where:

$\mathrm{W}_{\mathrm{b}}=$ Broilers body weight, $\mathrm{kg}$

$\mathrm{F}_{\mathrm{c}}=$ Broilers feed consumption, $\mathrm{kg}$

\section{$\underline{\text { Feed conversion ratio }(\mathrm{FCR})}$}

Broilers feed conversion ratio was determined as follows:

$$
\mathrm{FCR}=\frac{\mathrm{F}_{\mathbf{c}}}{\mathrm{W}_{\mathrm{b}}}
$$

\section{Production index (PI)}

Production index was estimated according to Saegh (1974) as follows:

$$
\text { PI }=\frac{W_{b}}{F C R} \times 100
$$

\section{Efficiency rate of production (ERP)}

The over all broilers performance in theses study was estimated by calculating Efficiency rate of production as follow:

E.R.P $=\frac{\text { meanliveweight } \times \text { percentage of lived }}{\text { feeding time } \times \text { feeding conversion ratio }} \times 100$

\section{RESULTS AND DISCUSSION}

\section{Effect of forced air heating with perforated duct on temperature stratification}

Temperature stratification during the first two days of brooding ( first brooding stage) inside the broiler house when using forced air heating system with and without perforated polyethylene duct is shown in Figure (2) In this period of life the recommended brooding temperature set is $34^{\circ} \mathrm{C}$. The data also showed that when using forced air heating system without duct the average temperatures underneath the ceiling were ranged between $28.8^{\circ} \mathrm{C}$ to $34.2^{\circ} \mathrm{C}$ at $15: 00$ and 08:00, respectively.. 

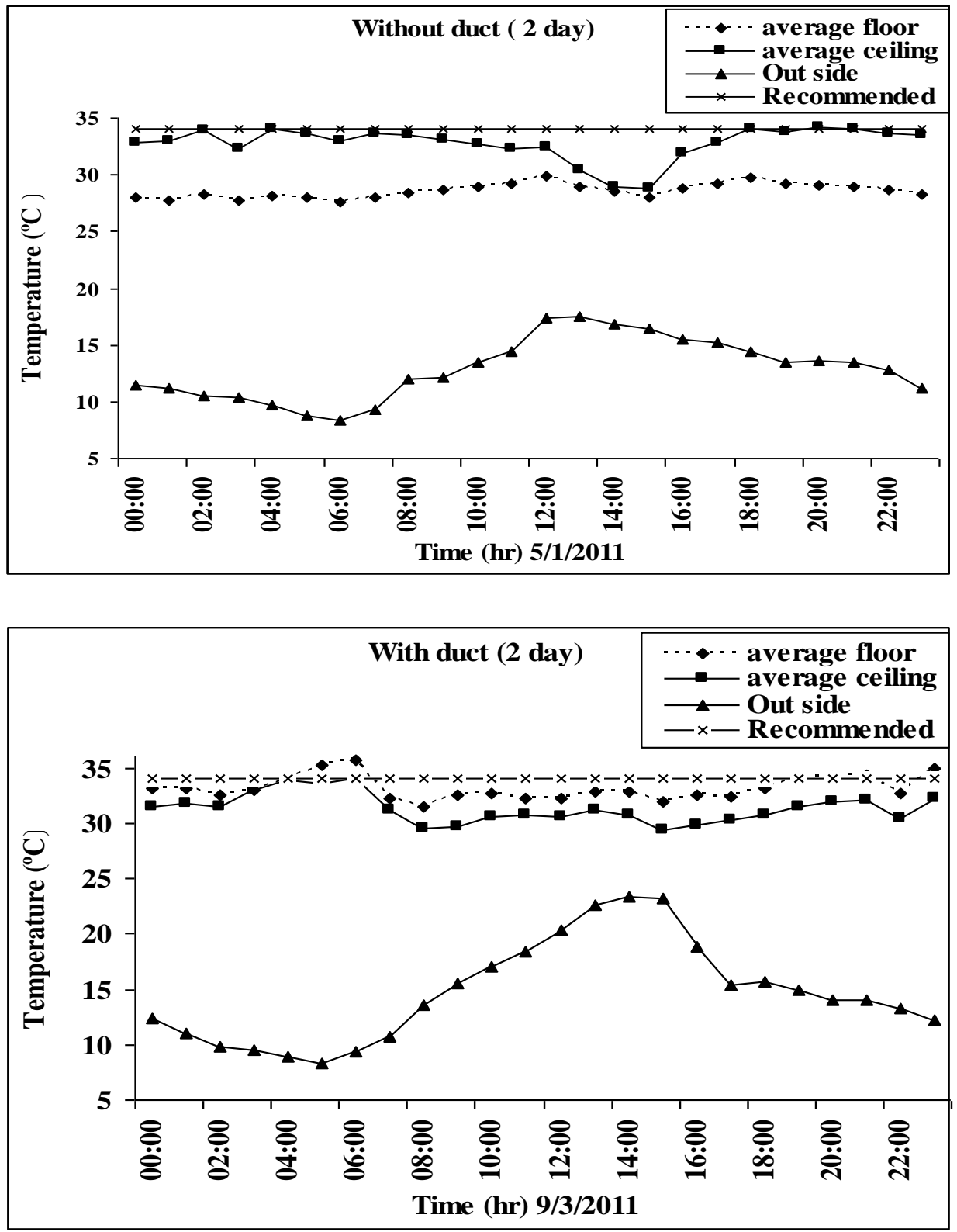

Fig(2) Hourly average air temperature in the house with and without duct

While the average temperatures just above the floor surface were ranged between $27.6^{\circ} \mathrm{C}$ to 29.95 . ${ }^{\circ} \mathrm{C}$ at $06: 00$ and $12: 00$, respectively. In this case, the temperature stratification was ranged between 0.4 to $5.93{ }^{\circ} \mathrm{C}$ at 
14:00 and 04:00, respectively. When using the forced air heating system with perforated polyethylene duct the average temperatures underneath the ceiling were ranged between $29.4^{\circ} \mathrm{C}$ to $34.02^{\circ} \mathrm{C}$ at 15:00 and 06:00, respectively. While the average temperatures just above the floor surface were ranged between $31.5^{\circ} \mathrm{C}$ to $35.64^{\circ} \mathrm{C}$ at $08: 00$ and $06: 00$, respectively. In this case, the temperature stratification was ranged between $-2.9^{\circ} \mathrm{C}$ to $0.043^{\circ} \mathrm{C}$ at $09: 00$ and 03:00, respectively

The daily average air temperature in the first week of the chicks brooding when using forced air heating with and without duct is shown in Fig. (3). During the first week the recommended temperature for the brooding chicks is $34{ }^{\circ} \mathrm{C}$ on the first day of chicks life and reduced gradually until reach to $32^{\circ} \mathrm{C}$ at the end of the week. Data showed that using forced air furnace without duct, the mean house temperature at the first day of brooding was $29.4^{\circ} \mathrm{C}$ when the mean outside temperature was $14.8^{\circ} \mathrm{C}$. On the third day of age the mean house temperature dropped to $27.8^{\circ} \mathrm{C}$ when the mean outside temperature was $14.9^{\circ} \mathrm{C}$. At the end of the first week the mean house temperature was $29.7^{\circ} \mathrm{C}$, when the mean outside temperature was $15.5^{\circ} \mathrm{C}$. While using forced air heating with duct the mean house temperature on the first day of the brooding was $30.7^{\circ} \mathrm{C}$ when the mean outside temperature was $14.1^{\circ} \mathrm{C}$. On third day of age the mean house temperature raised to $32.9^{\circ} \mathrm{C}$ when the mean outside temperature was $13.7^{\circ} \mathrm{C}$. At the end of the first week the mean house temperature was $29.4^{\circ} \mathrm{C}$, when the mean outside temperature was $15.1^{\circ} \mathrm{C}$. Consequently, using perforated duct help in rise the mean house temperature on the first day by $1.3^{\circ} \mathrm{C}$. The mean house temperature at the first week ranged between $27.8^{\circ} \mathrm{C}$ to $29.7^{\circ} \mathrm{C}$ when using heating system without duct. But, when using perforated duct for hot air distribution the mean house temperature ranged between $29.5^{\circ} \mathrm{C}$ to $32.9^{\circ} \mathrm{C}$.

\section{Effect of temperature stratification on broiler performance}

Broiler performance were estimated in the two successive cycles when using forced air heating with and without duct in terms of feed 
conversion efficiency, feed conversion ratio, production index and efficiency rate of production.

Feed conversion efficiency affected by temperature distribution inside the house. The relationship between the feed conversion efficiency and broiler age when heating broiler house with forced air heating system with and without duct revealed in Fig (4). Feed conversion efficiency decreased as the age of birds increased. Therefore, the feed conversion efficiency was $98.56 \%$ in the first week of age and reached to $60.4 \%$ at the five week of age. When the forced air heating system with and without duct was used, the feed conversion efficiency ranged between $99.6 \%$ on the first week of age and reached to $62.2 \%$ at the five week of age. Data showed that feed conversion efficiency increased when using perforated duct in hot air distribution because, in the first case the air come out from heater rise up to the house ceiling and let the birds zone cooler which made birds huddling to gather in groups and most do not seek out feed or water which adversely affected in feed conversion efficiency. But, when using perforated duct to distribute hot air the mean temperature in the bird's zone was close to the goal, so, birds were more comfortable and theses help in increasing feed conversion efficiency.

Feed conversion ratio is an indicator for broiler performance. The relationships between feed conversion ratio and broiler age when heating broiler house using forced air heating system with and without duct are shown in Fig. (5). Feed conversion ratio increased with increasing broiler in age, when heating broiler housing by forced air heating system without duct the feed conversion ratio was 1.01 at age of one week and increased to be 1.65 at age of five week. But, when using perforated duct to distribute heat inside the house, the feed conversion ratio was 1.00 at age of one week and increased to be 1.6 at age of five weeks. So perforated duct help in reduce temperature fluctuation inside broiler housing and prevent chicks from huddling and thus inhibit chick for feed consume and help in decreasing feed conversion ratio. 
Production index is dependent on live mass and feed conversion ratio. Fig. (6) shows the relationship between production index and broiler age when heating broiler house by forced air heating system with and without duct. Production index is increased with increasing broiler in age. Heating broiler housing by forced air heating system without duct revealed that, the production index was $12.8 \%$ at age of one week and increased to be $114.8 \%$ at age of five weeks. But, when using perforated duct to distribute heat inside the house, the production index was 14.9 at age of one week and increased to be $130.6 \%$ at age of five weeks. The perforated polyethylene duct helped in increasing body mass and decreased feed conversion ratio and thus lead to increase the production index.

Fig (7) shows the relationship between efficiency rate of production and broiler age when heating broiler house by forced air heating system with and without duct. Efficiency rate of production increased with increasing broiler in age until four weeks of age in both treatments and reduced to be $306 \%$ at five weeks, when heating the house by forced air heating system without perforated duct. When heating the house by forced air heating system with perforated duct in heat distribution it reduced to be $347 \%$ at five weeks. It is realized that, the efficiency rate of production was higher at the end of live when using perforated duct to distribute heat inside house, because it helps chicks to be warm.

\section{CONCLUSION}

Experimental work was conducted to reduce temperature stratification inside the broiler housing using perforated polyethylene duct in heat distribution. Temperature stratification was measured and broilers performances were also estimated. From the previous data it can be concluded that:

1-The perforated polyethylene tube was uniformly distributed the indoor air temperature throughout the broiler house, resulting in distributing the birds throughout the broiler house and not huddling together or sitting in the feed pans

2-Perforated duct increased the feed conversions efficiency, production index and efficiency rate of production from 60.4 to $65.2 \%, 114.8$ to $130.6 \%$, from 306.83 to $350 \%$ at age of five weeks, respectively. 

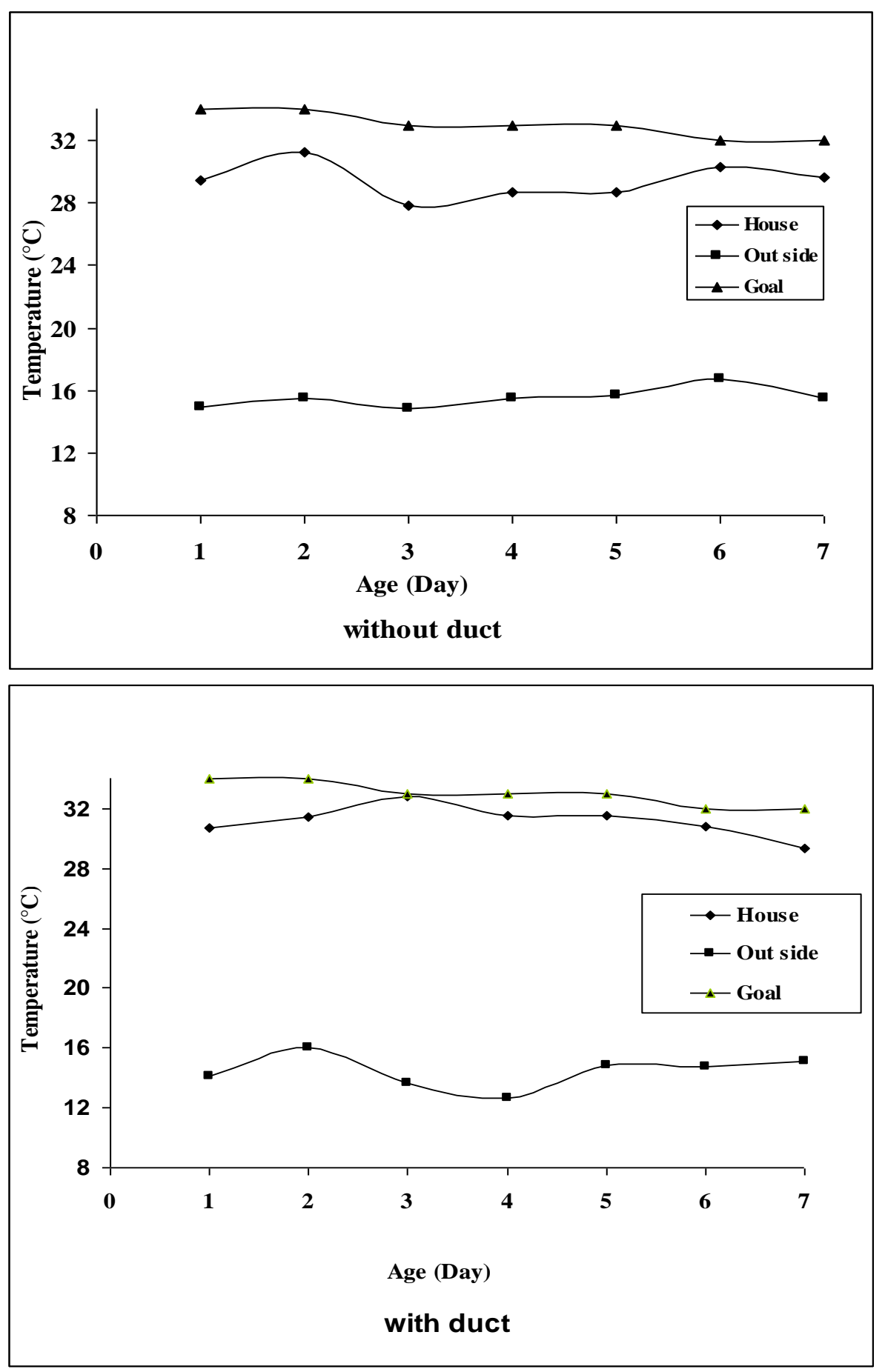

Fig(3) Average daily house temperature with and without duct 


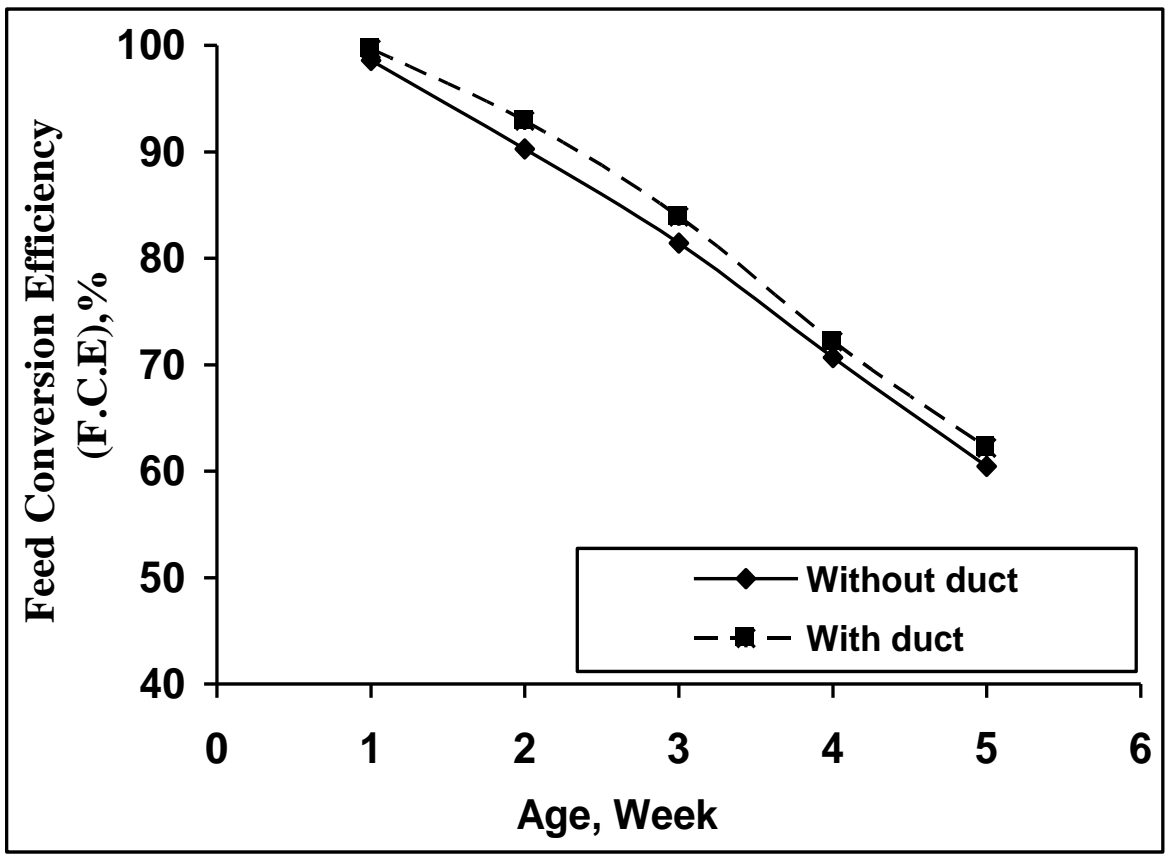

Fig(4) feed conversion efficiency with and without duct at different broiler age

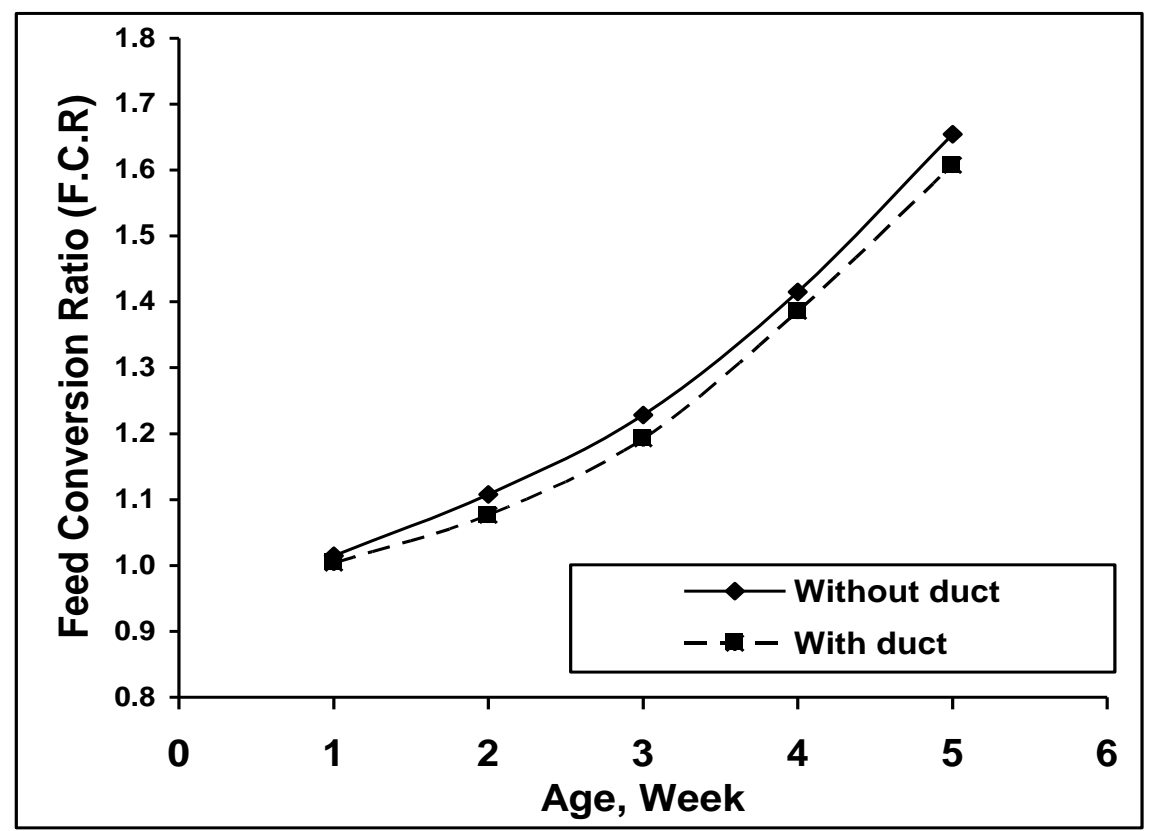

Fig(5) feed conversion ratio with and without duct at different broiler age 


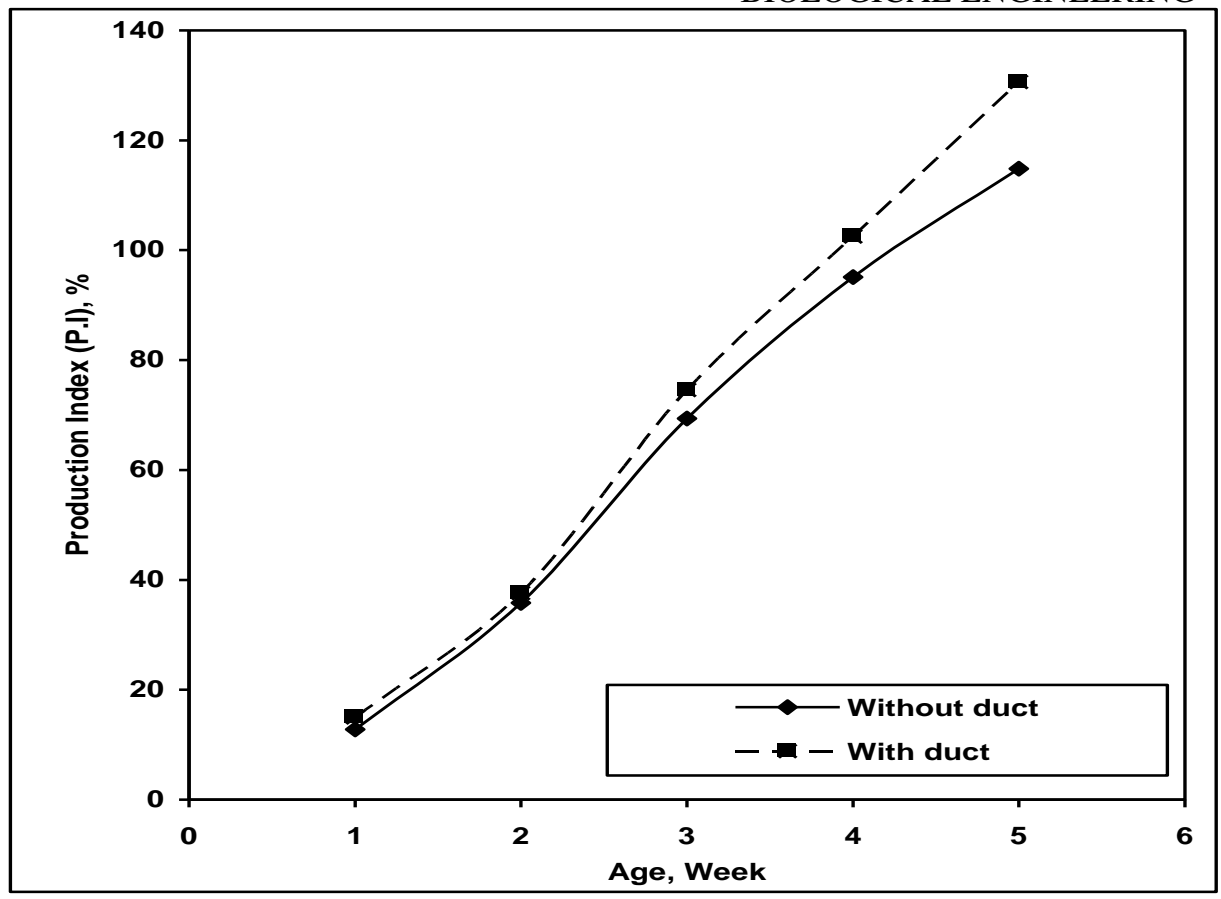

Fig(6) production index with and without duct at different broiler age

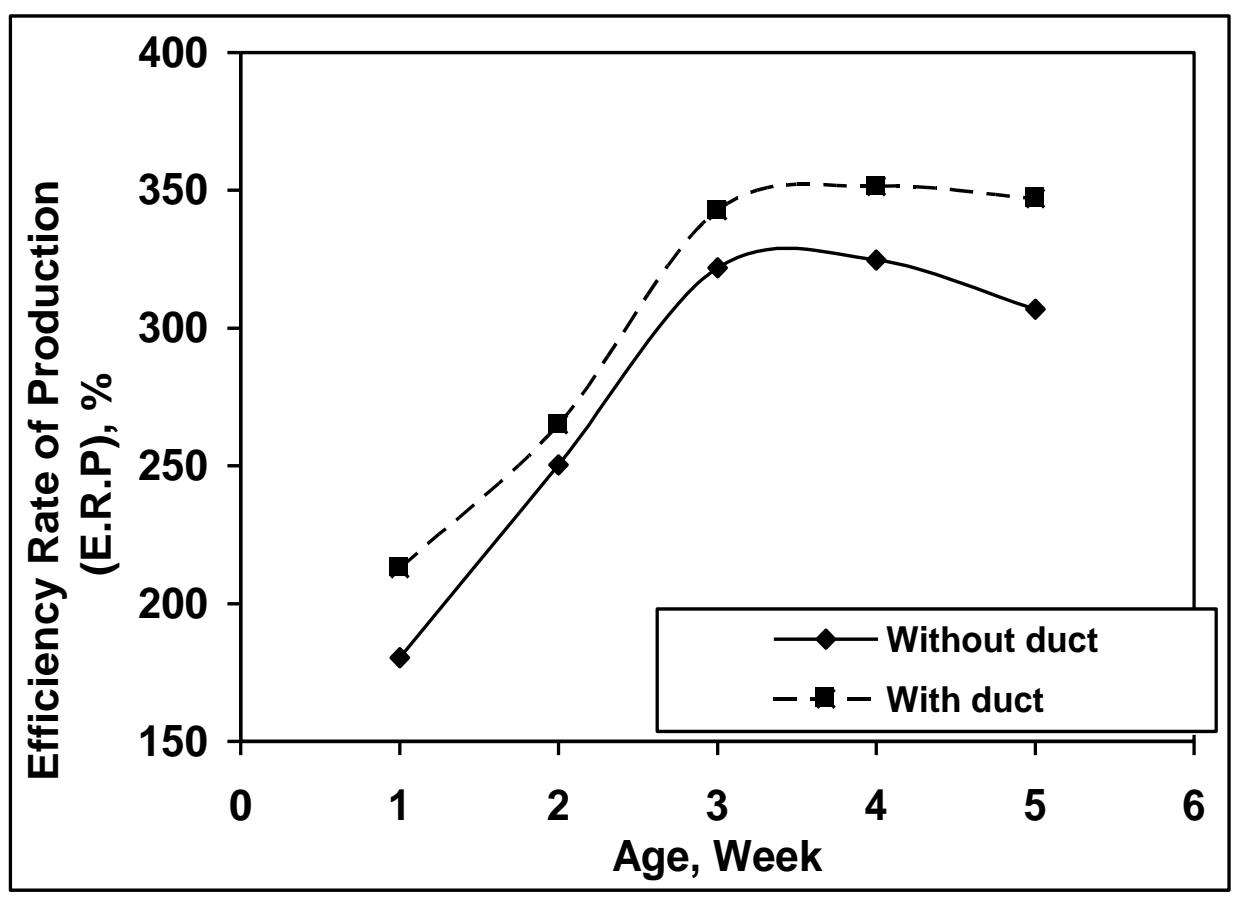

Fig(7) Efficiency rate of production with and without duct at different broiler age 


\section{REFERENCES}

Czaric, M and M.P. Lacy (2000a) "Heating system thermostat/sensor" Poultry Housing Tips, March University of Georgia Cooperative Extension Service

Czaric , M and M.P. Lacy (2000b) "Reducing temperature stratification in houses with forced air furnace" Thermostat/sensor, Poultry Housing Tips, March University of Georgia Cooperative Extension Service

Czaric, M. and B.D. Fairchild (2005) "Temperature Stratification during brooding" Poultry Housing Tips, February University of Georgia Cooperative Extension Service

Dozier, W.A., and J. Donald (2001) "Keys to successful brooding" The Alabama Poultry Engineering and Economics Newsletter. No. 14, November. Alabama Cooperative Extension System, Auburn University, Auburn, Ala.

Fairchild, B .D. (2009) "Environmental factors to control when brooding chicks" April University of Georgia Cooperative Extension Service

George A. D ; N .W. John ; and W.T. Lary (1997) "Poly-tube heating ventilation systems and equipment. Cooperative Extension Service, Univ. of Kentucky

Lacy, M. P. (19970 "The effect of cool temperatures on broiler performance" Poultry Housing Tips. January University of Georgia Cooperative Extension Service.

Saeght, A.S. (1974) "Poultry book" Samea, Baeroet, Lebno 


\section{الملخص العربيى}

\section{أثر نظام التدفئةعلى تطابق درجات الحرارة داخل مسكن لاجاج اللحم}

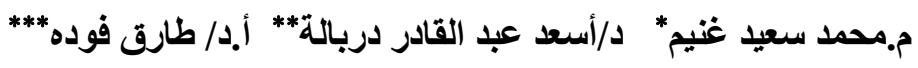

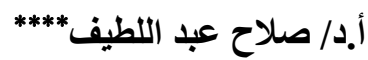

تعتبر مشكلة تطابق درجات الحر ارة مـن المشـاكل البيئية التى تو اجـه المربسى فى فصـل الثتاء خاصة فى المرحلة الاولى من عمر الكتاكيت وذللك لان دجاج اللحم من ذوات الدم الحار اي لها القدرة على تتظيم درجـة حر ارة جسمها ولكن هذه القدرة تبداء بعد عمر ع ا يوم حيث يبداء الكتكوت فى تنظيم درجة حرارة الجسم بعد هذا العمر مما يوثر سلبا على انتاجية الدجاج .

أجريت هذه الدر اسة فى مسكن لاجاج التسمين فى قريـة بابـل مركز تـلا بمحافظـة المنوفيـة حيث

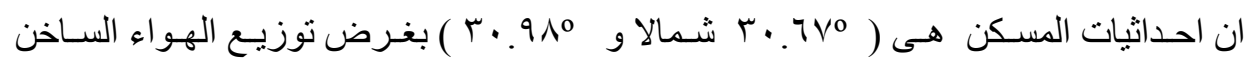

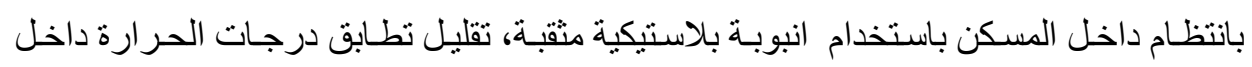
المسكن ، تقليل احتياجات الطاقة الازمة للتدفئة و زيادة كفاءة التحويل الغذائى. تم اجر اء التجربـة

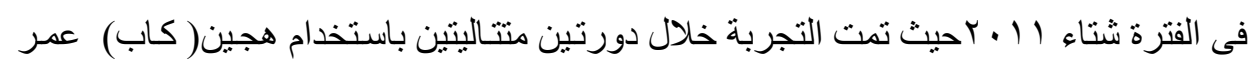
يوم و احد. الدورة الاولى تمت التدفئة باستخدام نظام الدفع الجبرى للهو اء. أمـافى الدورة الثانيـة تمت التدفئة ايضـا باستخدام نظـام دفع الهو اء السـاخن مـع استخدام انبوبـة مـن البولى اثيلين وتم

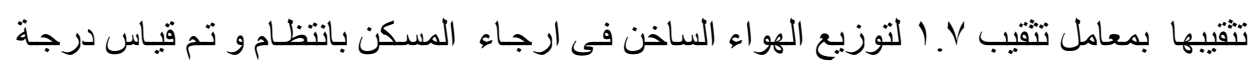

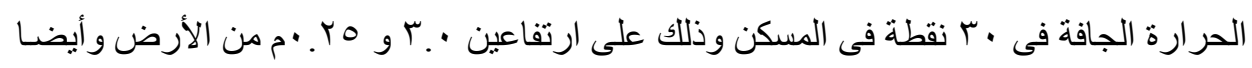

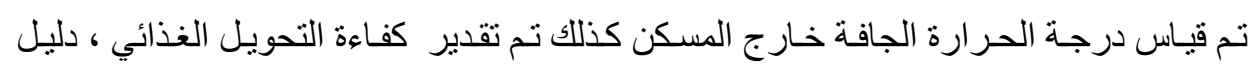
الإنتاج ، معدل كفاءة الإنتاج وكانت النتائج كالتالي:

عند استخدام نظام التدفئة بالدفع الجبري للهو اء بدون أنبوبـة مثقبـة كانت قيم الفرق فى درجـات الحر ارة بين سقف و أرضية المسكن تتر اوح بين 0.4 و 5.93 م .

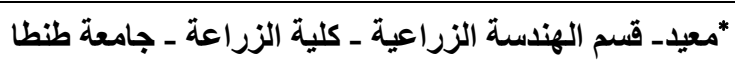

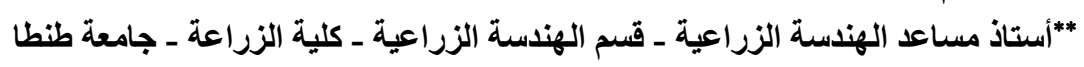

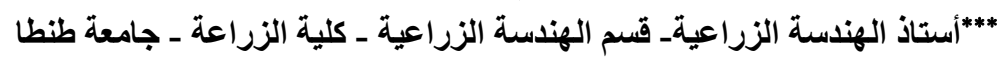

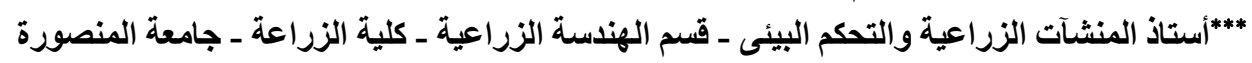


ولكن عند استخدام نفس النظام مع أنبوبة مثقبة من البولي ايثيلين لتوزيع الهواء السـاخن بانتظام

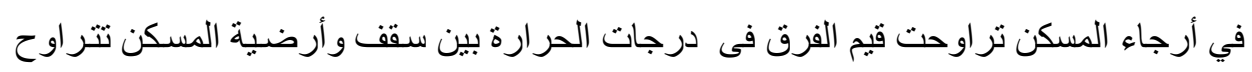
بين $2.9^{\circ} \mathrm{C}$ و 0.043 م و وذلك عند عمر يو مان .

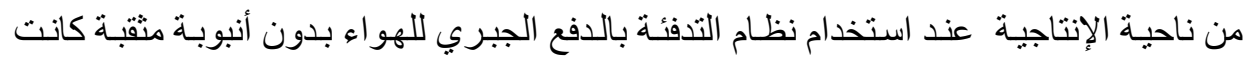

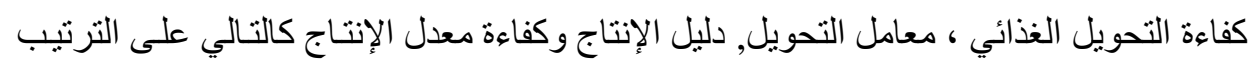

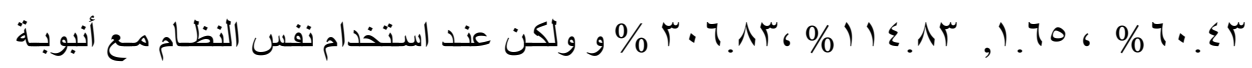

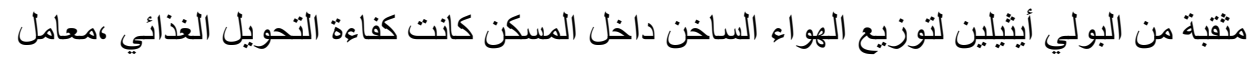

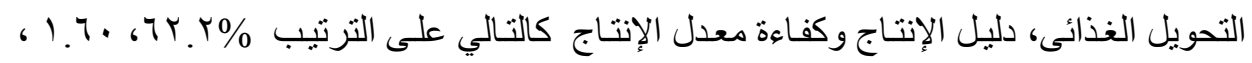

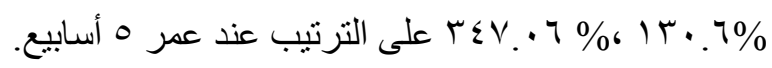

